\section{Organisational Adjustment and the Labour Market in New Zealand}

\section{Richard Harris and Bridget Daldy*}

\section{Introduction}

Post-war New Zealand enjoyed exceptionally low unemployment rates as compared to other industrialised countries, especially after the boom years of the 1960 s when unemployment rates rose in nearly all OECD countries. This can be explained by government policies regulating and protecting the economy from outside influences. Extensive use of high tariffs, import licensing and quotas meant that New Zealand had one of the highest levels of effective protection amongst OECD countries (OECD, 1990). The government also embarked on a "think big" campaign in addition to the active support given to a number of loss making government trading enterprises. The net result was that full employment was achieved through job creation and maintenance in those public and protected sectors shielded from foreign and domestic competition. The cost, however, was the reduced competitiveness of the export sector and "the creation of an insular, inefficient, increasingly rigid, inflation-prone economy which proved ill adapted to external shocks and to the challenges and opportunities of a rapidly changing world economy" (OECD, 1990: 13). Since 1984, and the incoming Labour Government's radical change of strategy (i.e. commitment to free market policies), employment levels have fallen and consequently unemployment has risen.

This current increase in unemployment is largely the result of restructuring, both by government deregulating and liberalising the economy, and by firms increasing efficiency and profitability. ${ }^{1}$ The outcome has been a rise in redundancies and non-replacement of staff as organisations have responded to a more competitive environment. This paper looks at the impact on 24 organisations which were found to be responsible for $85.6 \%$ of (gross) job losses during 1988-90 among organisations employing more than 10 workers in the Hamilton Statistical Division. Thus, in Section 1 we consider briefly the pressures that lead to restructuring at the organisational level; in Section 2 a model of restructuring based on an approach developed by Massey and Meegan (1982) is presented; and finally, the implications for the workforce are examined in section 3 . The paper ends with a summary and conclusion.

\section{* University of Waikato}

1 That is, the general downsizing in New Zealand employment is not associated directly with demand conditions world-wide. See Harris and Daldy (1992) for evidence that New Zealand's current unemployment problem is not cynical.

\section{Reasons for adjustment at the organisational level ${ }^{2}$}

For simplicity, we begin by considering changes affecting the demand for goods and services separately from factors affecting their supply, although to any organisation they obviously impact simultaneously, and are therefore interlinked. Both filter down to affect the demand for labour, in terms of the quantity and the quality (or type) of workforce required by organisations. Demand-side factors include both cyclical changes in demand, which coincide with booms and slumps in the business cycle, and longer-term shifts, such as those associated with product-life cycles, changing competition and technological change. All of these occur against a background of socio-economic (and thus political) changes affecting society. For example, as demographic changes occur (for example through an ageing population), as society becomes wealthier (or poorer), and as priorities change ( $c f$. the new concern with environmental issues, as incorporated into the Management Resources Act, 1990), there are changes in the "environment" surrounding the demand for goods and services. Another example, which has had a particular influence on the public sector, has been a shift in ideology away from government intervention in the economy towards a belief that the private sector (i.e. "markets") should allocate resources, with government only involved when there is an obvious case of a public good to be achieved (i.e. one where there are large external benefits/costs that individuals, or groups of individuals, cannot appropriate themselves) or where there is market failure and the resultant costs to society are significant.

Supply-side factors relate mainly to costs and efficiency, which enable an organisation to maintain (or increase) its market share. Such factors include the ability to achieve economies of size and scope, either through becoming larger (and reducing, for example, average fixed costs) or becoming smaller, if the organisation is too big, and there are gains from decentralisation and reorganising; the introduction of new technology; quality changes; and downsizing and/or reorganising the workforce. The business environment again is also important, as government actions impose a cost or benefit on organisations (for example, the large-scale protection of the economy that was a feature until recently would in the short-run be expected to allow organisations to grow, although the longer-term consequences, related to what might be termed a lack of business discipline or enterprise culture, are usually not favourable).

Clearly demand-side changes have been occurring, not least as a result of new technology leading to new ranges of goods and services, and thus increased market competition and a more uncertain business environment. Older, more established (and often primary) goods and services with low (or diminishing) value-added have had to compete in markets where quality and design have assumed much greater importance. The widespread development of global markets is also changing the terms of competition, and is associated with accelerated technological growth, more integrated capital markets, reduced information and transportation

2 Note, this paper is concerned with change at the organisational level, rather than the macroeconomic consequences for the labour market. On the latter see: Gray (1988), Houghton, et al. (1987), Melser et al. (1982), Murray-North Ltd (1989), National Organisation for Women (1982), Nicholls and Piease (1982), and State Services Commission: Waikato United Council (1982). 
costs, the liberalisation of trade barriers and the growth of the multinational corporation as the dominant form of economic organisation (Ashton, Maguire and Silsbury, 1990: 104). A recurring theme in the Porter Report for New Zealand (1991) is that "local-demand conditions provide little competitive advantage to New Zealand industry... In contrast to other nations where sophisticated local demand can be used to anticipate international trends, New Zealand exporters often do not take the local market seriously." (p. 199). Thus, it is argued that as well as affecting export potential, local-demand conditions are such that it is difficult to substitute local products for the kinds of goods imported, which are often high in value-added, since this would involve significant technological, managerial and capital resources, all of which are available to larger, multinational corporations and not to smaller local enterprises (Porter Report, 1991: 55).

As well as increased competition within sectors, because of globalisation and technological growth, there has also been a demand shift across sectors, away from primary and manufactured products towards services (Gershunny and Miles, 1983; Cyert and Mowery, 1987, ch.3). This has been reflected in sectoral output shifts that show that agriculture and production industries (mostly manufacturing) have usually declined relative to services (government, financial, business and personal services). It has been argued that the relative growth of the service sector may in part reflect the sector's higher income elasticities of demand; thus as the economy grows, average incomes rise and the composition of final demand shifts towards services. It has also been argued that post-war economic development moved into a "mature" stage within production-based industries after the 1960s. Hence, profits fell and labour (and energy) saving investment was important (especially given two oil price shocks in the 1970s). The industrialised economies responded with "a shift in the pattern of demand towards more labour-intensive sectors, with lower than average investment needs per unit of output" (Freeman, 1986: 111)

While the pressure to restructure builds up because of these longer term changes in demand, the process itself is usually speeded-up through some form of supply-side "shock". In the case of Britain in the early 1980s, this took the form of the oil price increase following the 1979 Iranian revolution, together with the exacerbating effect of a monetarist experiment conducted by the Thatcher government where demand was kept low, through a tight control of the money supply, in order to combat inflation. In New Zealand's case, government deregulation and liberalisation, together with stricter control of government expenditure and the money supply, has acted as the catalyst for the recent restructuring. Thus, organisations have implemented changes brought on by demand-side pressure, for example, developing new products, opening up new markets, and introducing new technology, while at the same time introducing measures to improve on costs and efficiency. This combination of demand and supply side responses has had its major impact in the labour market, as organisations attempt to introduce change through greater flexibility, especially in the workforce. Indeed, it has been stated that "growing uncertainty in product markets and processes may require a workforce which is capable of responding to as yet unknown changes in these dimensions" (NEDO, 1986).
Kanawaty, et al. (1989) argue that the introduction of advanced technology and the wider use of information systems has had at least two major impacts on the workforce: many of the changes are highly labour-saving (for example, robotics, automated machines), but not necessarily so in the long-run (especially when computer-aided systems of design and manufacture result in new products, new demand, and thus potentially higher employment). ${ }^{3}$ Secondly, the increased skills required when deploying new technology have meant that organisations have had to retrain and redeploy workers, and in many cases have shed those workers who for reasons of age, education or experience cannot adapt. Thus, new technology is changing both the occupational "mix" needed in organisations (with more technical staff required to operate the new systems, and less unskilled manual staff) and the skill content of existing jobs (broadening the range of skills and tasks performed, and requiring constant upgrading of skills to keep up with continuing change - see NEDO, 1986).

In line with such changes, the use of new technology is linked to new and more flexible forms of work organisation, often centred around productivity- and motivation-related team work (for example, quality circles, business clinics, campaign drives), and new forms of management organisation (for example, "flatter" organisations, with fewer tiers and much greater involvement between management and the general workforce) ${ }^{4}$ This has implications for industrial relations, especially as to whether changes can be introduced with the cooperation of trade unions both with regard to the impact on job profiles and to the consequences for pay, employment levels and health and safety. The traditional perception has been that trade unions have limited productivity growth through the negotiation of restrictive practices. Willman (1986), in his major study of the unions and industrial efficiency, quotes Ullman (1968: 340) who defines such practices as:

Excessive job fragmentation by craft unions, overmanning, double handling, excessive tea breaks or other forms of idle time, retention of the same number of machines per operative following the introduction of new and improved machinery, limiting (or 'pegging') output per worker under either time or incentive payment, limiting output of equipment, excessive overtime.

However, Willman (op.cit.) states that while he found some evidence of opposition to technological change by trade unions, on balance they are not a major obstacle to such change, even though restrictive practices still remain in many sectors. Going even further, Daniel (1987), using the British Workplace Industrial Relations Survey, 1984, found that: "... the reactions of workers and unions to technical change were generally very favourable ... indeed, workers and union officers emerged from our analysis as ... strongly in favour of

3 A study by Daniel (1987) of the impact of new technology on employment levels in Britain in 1986 A study by Daniel (1987) of the impact of new technology on employment levels in Britain in 1986
showed that manning levels declined in 19\% of plants (they went up in $11 \%$ with $70 \%$ unchanged), but showed that manning levels declined in $19 \%$ of plants (they went up in $11 \%$ with $70 \%$ unchanged), but when only larger workplaces where considered (employing over 200 workers) manning levels decreased
(especially among manual grades) in $40 \%$ of plants as a result of the introduction of new technology (especially among manual
(only $15 \%$ had increases).

4 As Piganiol (1989) points out: "... the sequence of events in the decision-making process is also altered. Previously, strategic positions were based solely on technical and economic criteria, and the labou factor was dealt with a posteriori from the logistical standpoint, belated consultations being sometime held as well with the workers' representatives. In the new approach the human factor is explicitly included from the very start" (p. 623). 
technical change, in terms of their practical response to particular changes" (Daniel, 1987: $182-183)^{5,6}$ Despite these findings, recent empirical evidence based on sophisticated statistical analysis of large-scale datasets has shown that plants with high union presences do not perform as well (financially) as other plants (Machin and Stewart, 1990; Crockett, et al, 1991), while unionised plants in Britain were more likely to experience a change in work practices in the 1980s partly, it has been argued, because of the introduction of anti-union legislation and partly because the higher level of unemployment led to the removal of restrictive practices (Machin and Wadhwani, 1991b).

Thus, the introduction of new technology, leading to flexible production methods, has meant that organisations have required matching flexibility from their employees. However, as pointed out by Kanawaty et al., op.cit., workplace flexibility has been occurring irrespective of the technological development of organisations. Organisations have sought to increase or reduce employment or wage levels with greater ease, to make more elastic use of skills, and to introduce non-conventional working arrangements, since each has a direct bearing on unit labour costs. The non-conventional working arrangements have resulted in flexible organisations comprising a permanent, regular, and skilled workforce coupled to a secondary workforce, hired to meet short-term production needs and thus more likely to be part-time (and probably female), temporary, lower skilled and lower paid (IMS, 1985; Atkinson, $1985){ }^{7}$ The growth of a secondary workforce, and indeed the ability of organisations to reduce employment levels, has been enhanced by reduced government regulation of labour markets (for example, through encouraging more flexible, enterprise- or even plant-based, employment contracts, not introducing statutory severance payments and reducing the scope and levels of minimum wages and other statutory obligations to temporary workers).

Case studies of change at the organisational level have shown that the above influences have been occurring in many countries. Goodman (1989) presents case studies of three restructuring manufacturing firms in the UK which confirm that "in an attempt to survive the recession, many manufacturing companies closed plants, contracted their labour forces, explored new products and markets, altered their production processes and introduced more efficient working practices" (p. 601). Certain key elements were identified (p. 602), which included increased numerical flexibility (i.e. downsizing of workforces and the greater use of subcontracting, part-time and fixed term contracts for "peripheral" labour tasks in uncertain market circumstances) and functional flexibility (ie. the redrafting of job definitions). Piganiol (1989) considers the impacts and means of restructuring in three French companies, and many of his findings are similar to those pertaining in Britain. This uniformity of experience is also apparent in case studies of enterprises in Asia, presented by Edgren (1990). Again, increasing the flexibility of the workforce through core-periphery arrangements, payments-by-results, the impact of technological change, and new systems of collective bargaining with unions feature prominently. Case studies of New Zealand organisations fit within the international experience; for example, Ammon (1989) has looked at the 1987 restructuring programme of

5 This finding has been substantiated using the same database by Machin and Wadhwani (1991a).

6 With regard to the US, Kassalow (1989) cites several cases where unions and management have cooperated with the introduction of new technology.

7 Storper and Scott (1990), in their discussion of post-Fordist production methods, extend the analysis to look at the impact of restructuring on local labour markets.
Electricorp which included, inter alia, reduced staffing levels (partly through removing a tier of management), reorganising working practices to cover a wider range of tasks (which also involved the use of more micro-technology and less staff), and the use of contract staff to cover peak demand.

\section{Restructuring the organisation}

Needing to reduce costs and increase efficiency against a background of deregulation and increased market competition, as well as long-term changes in technology and production methods, organisations can adopt various possible courses of action. Savage and Bollard (1990) discuss diversification into other sectors, short-term holding, revitalisation (such as layoffs, improving product and factor mix, and adopting new technology), and disinvestment (or exit) strategies as options. Massey and Meegan (1982) attempt to classify employment decline in Britain on the basis of rationalisation, intensification or investment and technical change. These, and other comparable approaches, mean that it is possible to group organisations and industries and consider common factors that distinguish a particular strategy. This study has chosen to adopt the Massey and Meegan approach, and categorise each of the case study organisations on the basis of whether their response to change was to rationalise, intensify or undertake investment in new technology. ${ }^{8}$ The allocation of organisations to a particular grouping was done using an appropriate statistical technique (in this instance cluster analysis), and then each grouping or "cluster" was examined to ensure that it displayed the characteristics of the appropriate restructuring strategy.

Massey and Meegan, op.cit., describe rationalisation as disinvestment ie. the complete or partial closure of plants, the scrapping of capital equipment and cut-backs in the labour force. It is generally the result of a lack of profitability, where organisations downsize in order to reinvest elsewhere or, more likely in the shorter term, to reduce costs to meet falling sales (and/or market share) and thus revenue. The overall strategy is to shrink, with the eventual outcome being either exit from the industry (if demand does not improve) or continuation on a smaller scale. This strategy is not usually linked to revitalisation, either because this is not a viable option (for example, lack of funds, a low technology industry, etc.) or because management prefers to adopt a holding strategy. In terms of key indicators, rationalisation is associated with rapid cut-backs in employment and investment levels together with falling capacity in a smaller number business units, while sales and profits are falling relatively fast. There is little or no change in the use of new technology, the development of new products, and the introduction of new work practices, although there may be an attempt to open up new markets. Generally, the organisation's share of the market is expected to improve as rationalisation reduces costs and allows the organisation to become more competitive.

8 It has been pointed out to us by a referee that these are not necessarily mutually exclusive, especially for multi-divisional organisations. However, for the purposes of this paper we have sought to categorise each of the case study organisations into one group for the purposes of our subsequent statistical analysis. While we believe that is unlikely to bias our results in the present context, we nevertheless accept the point made by the referee. 
Intensification is a reorganisation of production associated with employment decline whereby capacity is not reduced and there is no major new investment in new forms of production; instead, the major aim is to increase labour productivity. This increase in output-per-worker can be achieved through changes in work practices to increase worker flexibility and thus often to reduce overmanning. Intensification is essentially a cost-cutting exercise often used to increase the organisation's competitiveness within a market that is declining overall. As such, it may be a preferred option vis a vis an alternative like major technical change, during periods when profits, liquidity and growth of output are restricted. Thus, intensification carries less risk in the short-term, and may lead into future new investment and technical change. The key indicators are falling employment levels and labour costs (as a proportion of all costs), coinciding with increasing profits and market share. Labour productivity improves, and production of goods and services is often more capital intensive, but there are not likely to be major changes in investment, new product developments, new technical changes and the opening-up of new markets.

Table 1

Restructuring strategies: key economic indicators

\begin{tabular}{llll}
\hline Indicator & Rationalisation & Intensification & $\begin{array}{l}\text { Investment \& } \\
\text { technical change }\end{array}$ \\
\hline Employment & -- & $-(-)$ & $-(+)$ \\
Sales & - & + & + \\
Profitability & - & ++ & $-(+)$ \\
Market share & ++ & + & + \\
Labour costs & - & $-(-)$ & $-(-)$ \\
Additional plant & - & nc & ++ \\
Additional buildings & - & nc & $+(+)$ \\
Production capacity & - & nc & + \\
No. of business units & - & nc & + \\
New products & nc & nc & + \\
New markets & + & nc & + \\
New technology & nc & nc & + \\
New work practices & nc & + & + \\
Labour productivity & nc & + & ++ \\
Capital intensity & nc & + & ++ \\
\hline
\end{tabular}

Note: + increase; - decrease; nc no change.

In comparison, employment losses resulting from investment and technical change are directly the result of large investments embodying labour-saving new technology. Accompanying this change are increases in capacity, often in conjunction with relocation to new sites, new product developments, new markets being supplied, and new work practices being introduced to coincide with the introduction of new techniques of production. While this strategy is intended to reduce costs and improve efficiency, the short-run growth in sales may not be accompanied by an immediate increase in profitability as change is effected. It is also possible that net employment losses are relatively small, given that the organisation is likely to move to a higher growth path. If major new investment in the production process occurs during a period of overall constraint on growth (primarily associated with external demand conditions in the national or international economy), the prime motive of this strategy may be "defensive"; i.e. to improve profit rates and market shares (and not lag behind competitors) rather than to move to a higher growth path. In this situation, employment loss and profit gain are likely to be larger, and increases in capacity (and relocation) may be limited.

The three strategies outlined are summarised in Table 1 on the basis of certain key economic indicators. Information was collected (by postal survey) on employment contraction in the Waikato workforce during 1988-1990 period. A sample of plants in the Hamilton Statistical Division were randomly chosen using the Department of Statistics' Business Directory, with the sample corresponding to all plants employing more than 500 workers, $75 \%$ of plants employing 100-499, 50\% employing 50-99 and 25\% of plants employing between 10 and 49 workers. This gave 266 organisations (operating some 380 plants), and these were contacted for information on the number of staff reductions initiated by the organisation in their Waikato workforce in the two year period. Nearly 190 organisations responded to the survey, resulting in 186 useable returns. After weighting the sample to bring it up to the population total, the response rate was $66.3 \%$ on the basis of the number of returns, and $82.2 \%$ in terms of the level of employment covered (this indicates that the response rate was higher for the larger employers). Thus, of the nearly 51,000 employees in the Waikato in $1990,{ }^{9}$ the survey obtained responses covering some 41,700 workers.

Having obtained information from Waikato organisations on staff reductions, those organisations primarily responsible for job losses were selected for a follow-up interview at their headquarters. There were 33 organisations that accounted for nearly $94 \%$ of gross job losses through natural wastage and redundancies. Of these, 26 organisations (responsible for $85.6 \%$ of the relevant gross reductions) were selected for interviews. Two did not respond (one had closed before an interview could be arranged and the other failed, after several attempts, to provide the information required). The remaining 24 organisations interviewed, which accounted for 79,103 employees in 1988 (and 62,168 by mid-1990), covered the following sectors: coal mining, meat processing, dairy processing, newspapers, precast concrete products, fabricated steel products, electrical machinery, building and non-building construction, wholesale timber materials, supermarkets, railways, post \& telecommunications, banking, databank business services, cleaning services, and government (central and local). (The two non-respondents operated in the clothing and research services sectors).

Before analysing the information obtained from the 24 case study organisations, we present some background analysis of the 1986-1990 employment changes occurring in those industries to which these organisations belong. The data used for this exercise was obtained from the Economy-Wide Census for New Zealand, 1986/87, matched to employment information on business units/plants contained in the Business Directory. Thus accounting data on organisations and plants (for the 1986/87 period) was linked to the number of business units operated (and their employment levels) for the years 1987-90. Only data for units belonging

9 Note, this figure only covers plants employing over 10. 
to organisations employing at least 25 individuals were obtained, ${ }^{10}$ but this still resulted in information on over 4,600 business units. Generally, employment contraction rather than tota closure was responsible for the majority (nearly 62\%) of all losses, although there were large numbers of jobs shed as a result of closures in the meat processing, clothing, structural steel fabricating, construction, wholesale timber and post \& telecommunications industries. In relative terms, the percentage of 1987 employment lost due to closures was highest in post \& telecommunications (37.6\%), followed by clothing $(27.2 \%)$, structural steel fabricating $(25.6 \%)$, and non-residential buildings $(22.3 \%)$. The lowest was in railways $(1.8 \%)$. The highest percentage of jobs lost due to contraction was in railways $(60.8 \%)$, coal $(45.6 \%)$, other electronics $(43.5 \%)$, non-residential buildings (39.9\%), post \& telecommunications $(39.7 \%)$, and cleaning services $(36.5 \%)$. The supermarket industry actually achieved a $4.9 \%$ increase in employment over the period.

As to how the Waikato (as defined by the Hamilton Statistical Division) performed vis a vis the rest of New Zealand, the Waikato experienced relatively greater losses in the precast concrete, structural steel fabricating (which almost disappeared in the Waikato by the end of 1990), non-residential buildings, other construction, supermarkets, and research services industries. In meat processing, dairy products, clothing, other electronics, timber materials, railways, and cleaning services there were relatively greater losses in the rest of New Zealand (with the remaining industries - coal, newspapers, post $\&$ telecommunications, banking and databank services - experiencing similar losses across the two areas). In general, across all industries, there is no statistically significant difference between the Waikato and the rest of New Zealand.

Thus it can be seen that the organisations selected for further study belonged to industries that were experiencing different degrees of job loss ( $c f$. dairy products and supermarkets with post $\&$ telecommunications and construction). Information relating to the percentage change in employment, the percentage change in sales (or operating budgets if the organisation was not a commercial enterprise), changes in profitability (return on assets), changes in the number of business units operated, and changes in investment in plant and equipment over the previous two years was used, together with the financial performance of the organisation compared to its competitors, to group the 24 case study organisations into categories.

Rather than subjectively arrange organisations into what would appear to be appropriate groups, the more objective technique of cluster analysis was used ${ }^{11}$ which essentially is statistical procedure that links cases on the basis of their proximity to each other to form agglomerations (or clusters); initially there are as many clusters as there are cases, and groupings are sequentially formed until all cases are joined together into one cluster. The number of clusters that "best" represents the data available is a subjective issue, although the technique does provide information on the distance between disjoint clusters which helps to avoid grouping together cases which have little (or no) relationship with each other.

10 Note data on certain industries were not available from the Economy-Wide Census; thus the backgroun discussion presented here only relates to 20 of the 26 organisations identified for further case study work.

11 See, for example, Romesburg (1984).
Using this approach, four clusters were identified that appeared to correspond to the restructuring strategies set out in Table 1 . The first two clusters represented differing degrees of rationalisation, while the next two clusters covered, respectively, intensification and investment $\&$ technical change. The results are set out in Table 2 , which reports the values of key indicators for each organisation and to which cluster they belong. It is clear that the first two clusters represent those organisations that experienced the greatest decline in employment, sales and plant numbers; sales and plant numbers in cluster three were generally unchanged; and the remaining organisations experienced a positive growth in sales over the previous two years and some small growth in plant numbers. Table 1 shows that rationalisation is more likely to be linked to declining profitability, and this pattern indeed emerged for the organisations in the first two groupings in Table 2, viz. the other agglomerations (although for two public sector organisations classified as part of the rationalisation group, the return on assets substantially increased from a very low base). Labour costs are more likely to decline for organisations embarked on a process of intensification or investment in new technology and, by and large, Table 2 shows that there is some support for this assertion. Investment in fixed assets such as plant and machinery is expected to increase as we move away from rationalisation towards strategies involving the adoption of new technology; this pattern is generally present although there are two prominent outliers (a dairy company and a government SOE).

The overall results of the clustering exercise suggest that the classifications put forward by Massey and Meegan op.cit. are an appropriate description of the strategies adopted by the 24 organisations for which information is available. This is tested by sorting each of the key economic variables into the three strategic groups and considering if differences in the means across groups follow the expected pattern for each variable. The results of this exercise are presented in Table 3. 


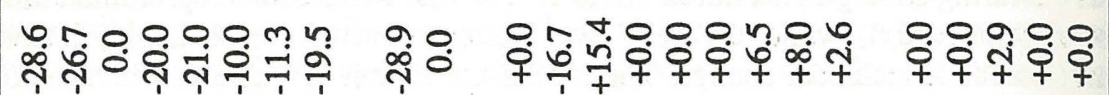

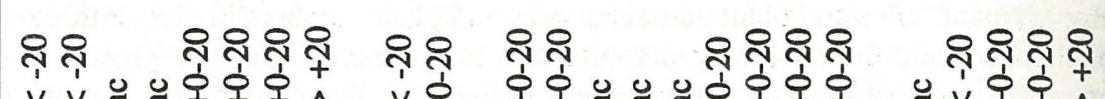

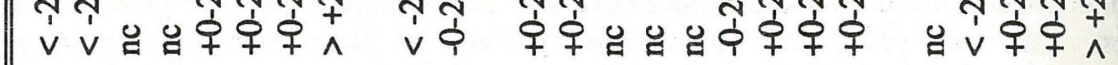

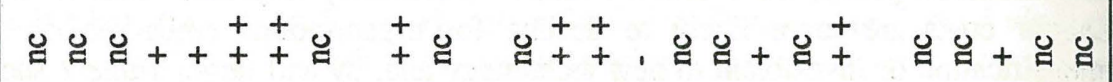

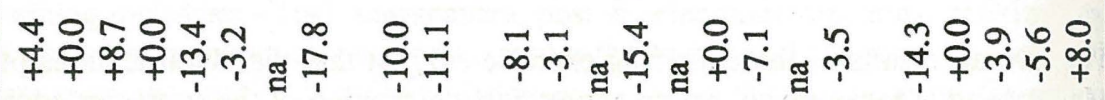

$, 1, \stackrel{+}{+}+\stackrel{+}{+}:, \quad,+++,+,+\stackrel{+}{+}++\stackrel{+}{+}++$

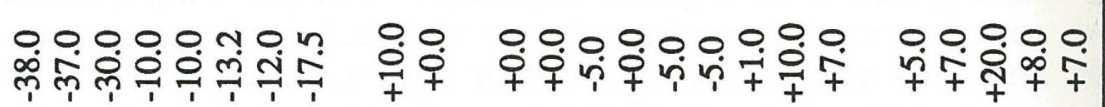

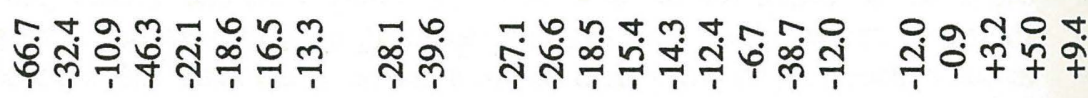

mathanha hm mmmemmotatatat

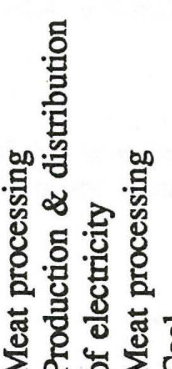

总

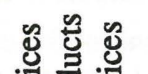

Table 3

Mean values of key economic variables across strategic groups

\begin{tabular}{|c|c|c|c|c|}
\hline Indicator & Rationalisation & Intensification & $\begin{array}{l}\text { Investment } \\
\& \text { technical } \\
\text { change }\end{array}$ & \\
\hline Employment change (\%) & -28.3 & -19.9 & -6.6 & $* * *$ \\
\hline Sales growth $(\%)$ & -17.5 & -1.8 & 9.1 & **** \\
\hline Profits $(1=++$ to $4=--)$ & 2.7 & 2.2 & 1.7 & ** \\
\hline Market performance & & & & \\
\hline$(-1=--$ to $3=++)$ & 1.0 & 0.5 & 0.1 & * \\
\hline Labour costs (\%) & -3.9 & -7.5 & -3.2 & \\
\hline Additional plant & & & & \\
\hline $\begin{array}{l}(1=>+20 \% \text { to } 5=<-20 \%) \\
\text { Additional building }\end{array}$ & 3.4 & 2.9 & 2.0 & $* *$ \\
\hline$(1=>+20 \%$ to $5=<-20 \%)$ & 3.8 & 2.9 & 2.5 & $* *$ \\
\hline $\begin{array}{l}\text { Production capacity } \\
\text { (1=full to } 3=\text { much below) }\end{array}$ & 2.1 & 1.7 & 1.5 & $*$ \\
\hline In no. of units $(\%)$ & -18.3 & 0.6 & 1.9 & $* * *$ \\
\hline $\begin{array}{l}\text { New products ( } \% \text { of sales } \\
\text { associated with) }\end{array}$ & & & & \\
\hline $\begin{array}{l}\text { associated with) } \\
\text { New markets }(1=\text { yes; } 2=\text { no) }\end{array}$ & $\begin{array}{r}22.1 \\
1.2\end{array}$ & $\begin{array}{r}13.7 \\
1.1\end{array}$ & $\begin{array}{l}2.9 \\
1.3\end{array}$ & \\
\hline New technology & & & & \\
\hline $\begin{array}{l}\text { (\% of workers associated with) } \\
\text { New work practices }\end{array}$ & 50.0 & 38.7 & 37.5 & \\
\hline (\% of workers associated with) & 61.1 & 55.6 & 65.7 & \\
\hline Productivity growth (\%) & 10.8 & 18.2 & 15.7 & \\
\hline Capital intensity growth (\%) & 25.8 & 20.2 & 9.6 & ** \\
\hline
\end{tabular}

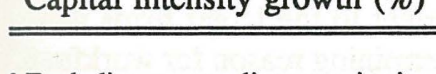

"Excluding two outlier organisations
Tests of a linear relationship across groups is statistically significant at *** $1 \%$ level; ** $5 \%$ level; and * $10 \%$ level

The patterns for employment change, sales growth, profitability, market performance, additions to fixed assets, production capacity and plant numbers are (significantly) in accord with prior expectations based on the three strategies for restructuring. Changes in labour costs are also in line with the pattern predicted ( $c f$. Table 1), although the difference across groups is not statistically significant. New product development, the introduction of new technology and work practices, does not conform to expectations, with most organisations undertaking similar changes in these areas. Productivity growth is certainly higher in organisations that did not rationalise, but not the highest in organisations allocated to the investment and technical change sub-group. Lastly, the growth in the capital-labour ratio was highest for organisations with the largest declines in employment i.e. those which rationalised (and, to a lesser extent, intensified). This suggests that in the short-term, the predicted sequence set out in Table 1 is not particularly likely, although the long-term growth in capital stocks may result in higher capital intensity for organisations embarking upon a strategy of investment and technical change. 


\section{Restructuring the workforce}

Rationalisation results in relatively more labour being shed, a cut back on the number of production units in operation, and undertaking less investment, when compared to organisations that reduce gross employment levels through alternative strategies. Against this background, we now specifically consider the methods used to restructure the workforce, including the main reasons organisations stated for workforce reduction, where decisions were made, whether alternatives to workforce reduction were considered and/or implemented, the order of sequencing of job losses (if any), and which categories of workers have borne the brunt from a downsizing of workforces. When discussing workforce restructuring, we will also test for (i) any correlation with the overall restructuring strategy adopted (as identified in the last section); (ii) any relationship with 1988 employment size (divided into four equalsized groups); and (iii) any relationship with changes in ownership since the end of 1987 (three groups, comprising no change, private sector change, public sector change).

Initially, the 24 case study organisations were asked to rank among six main reasons for gross reductions in the workforce, with five of the reasons being pre-selected areas for response The results (Table 4) show that nearly every organisation ranked the need to improve competition and reduce costs as the most important reason, with reorganisation of work methods close behind. Lack of demand (and the associated response of reduction in budgets) was not cited as being of great importance, which confirms once again that the background to restructuring has been the longer-term need to respond to increased market competition, rather than short-run cyclical down-turns in demand. None of the reasons given for downsizing are strongly associated with any of the particular restructuring strategies discussed in the last section (except the other reasons category, which was not very important). Rather, organisations in common were intent on introducing new work methods and improving efficiency. However, the employment size of the organisation was an important factor with smaller firms being less likely to rank automation, reorganised work methods, and improved competitiveness highly. These factors were much more important to the larger firms while smaller organisations ranked lack of demand as a dominant determining reason for workforce reductions. Changes in ownership were not a statistically significant factor influencing the ranking decisions made by organisations.
Table 4

Main reasons for gross reductions in the workforce 1988-90

\begin{tabular}{lllllll}
\hline Reason & Rank & \multicolumn{5}{c}{$\begin{array}{l}\text { Significance of } \\
\chi^{2} \text { test }^{\mathrm{b}}\end{array}$} \\
\hline \hline $\begin{array}{l}\text { Lack of demand for } \\
\text { products or services }\end{array}$ & mean & median & (i) & (ii) & (iii) \\
$\begin{array}{l}\text { Automation/mechanisation/ } \\
\text { new equipment }\end{array}$ & 2.46 & 1.0 & 0.48 & 0.41 & 0.36 \\
$\begin{array}{l}\text { Reduction in budget/ } \\
\text { cash limits }\end{array}$ & 2.33 & 3.0 & 0.61 & 0.05 & 0.45 \\
$\begin{array}{l}\text { Reorganised working methods/ } \\
\text { relocation/integration }\end{array}$ & 2.21 & 2.5 & 0.47 & 0.15 & 0.24 \\
$\begin{array}{l}\text { Improved competitiveness/ } \\
\text { efficiency/cost reduction }\end{array}$ & 3.96 & 5.0 & 0.99 & 0.07 & 0.72 \\
Other & 5.04 & 5.5 & 0.36 & 0.03 & 0.28 \\
\hline \hline
\end{tabular}

a Ranked $6=$ most important down to $0=$ not a consideration

"Ranked $6=$ most important down to $0=$ not a consideration
b (i) Probability of accepting the hypothesis of "no difference across the three restructuring strategies" based on the Kruskal-Wallis test

(the Kruskal-Wallis test

(ii) Probability of accepting the hypothesis of "no difference across four 1988 employment size-bands"
(iii) Probability of accepting the hypothesis of "no difference across three classes of change in ownership since (iii) Pro

Employers were next asked to provide information on who decided that workforce reductions were necessary, and who determined the methods of reduction. Three options for reply were available: Head Office only, joint HO/local decision, and local management only. The purpose of the questions was to see the extent to which decision-making was centralised, and whethe local conditions were taken into account. The results (Table 5) show that Head Offices had the over-riding input into deciding both that reductions were necessary and which methods to use. This was true irrespective of the overall restructuring strategy for an organisation or the type of ownership change occurring. For decisions on the method of reducing the workforce, there was an association with the size of the organisation (as shown by the chisquared value based on the Kruskal-Wallis test), with larger organisations being much more likely to devolve to some element of local decision making. 
Table 6

Overall policy and alternatives considered relating to reductions in the workforce 1988-90

Table 5

Management level decision-making relating to reductions in the workforce, 1988-90

\begin{tabular}{|c|c|c|c|c|c|}
\hline \multirow[t]{2}{*}{ Management Level } & \multicolumn{2}{|c|}{ Frequency $(\%)$} & \multicolumn{2}{|c|}{$\begin{array}{l}\text { Significance } \\
\text { of } \chi^{2} \text { test } \\
\end{array}$} & \multirow[b]{2}{*}{ (iii) } \\
\hline & & & (i) & (ii) & \\
\hline Head Office only & 50.0 & \} & & & \\
\hline Joint HO/local & 45.8 & \} & 0.63 & 0.32 & 0.63 \\
\hline Local only & 4.2 & \} & & & \\
\hline \multicolumn{6}{|c|}{ Deciding method of reduction } \\
\hline Head Office only & 45.8 & \} & & & \\
\hline Joint HO/local & 45.8 & \} & 0.58 & 0.04 & 0.58 \\
\hline Local only & 8.3 & \} & & & \\
\hline
\end{tabular}

See Table 4 for explanation

Organisations were asked if there was an overall policy whereby workforce reductions are considered (i) as an automatic response to the need for restructuring; (ii) as part of the "package" of responses when restructuring; (iii) as only necessary when other measures are likely to take too much time to have an effect; and (iv) as the last response when all else fails. They were also requested to provide information on whether alternative measures were used in conjunction with (or to avoid) workforce reduction. Table 6 shows that downsizing was fairly automatic, and other alternative measures were used in conjunction with (rather than as an alternative to) workforce reductions. Furthermore, the overall strategy of restructuring is important. Organisations embarked upon rationalisation were more likely to opt for an automatic need to reduce employment numbers, while those undertaking intensification (vis a vis organisations using other strategies) were more likely to use measures other than employment reductions in conjunction with (rather than to avoid) downsizing the workforce.

\begin{tabular}{|c|c|c|c|c|}
\hline \multirow[t]{2}{*}{ Management response } & \multirow[t]{2}{*}{$\begin{array}{l}\text { Frequency } \\
\%\end{array}$} & \multicolumn{3}{|c|}{$\begin{array}{l}\text { Significance of } \\
\chi^{2} \text { test }^{2}\end{array}$} \\
\hline & & (i) & (ii) & (iii) \\
\hline Overall policy & & & & \\
\hline Automatic response & 29.2 & & & \\
\hline Part of the "package" of responses & 45.8 & & & \\
\hline Only when other measures take too long & 12.5 & 0.15 & 0.97 & 0.41 \\
\hline The last response when all else fails & 12.5 & & & \\
\hline \multicolumn{5}{|l|}{ Alternative measures implemented ${ }^{\text {}}$} \\
\hline To avoid workforce reductions & 25.0 & 0.13 & 0.23 & 0.97 \\
\hline In conjunction with workforce reductions & 70.8 & 0.09 & 0.55 & 0.65 \\
\hline
\end{tabular}

- See Table 4 for explanation

b \% answering that this option was used. Note the sum of the two does not add to $100 \%$ since one respondent did not use either option

As to which measures were implemented in addition to workforce reductions, alternatives were given separately under the broad headings of "marketing" and "workforce" alternatives. With the former, there were five choices to be ranked $(0$ to 5$)$ covering promotions of sales through new/existing markets, cutting product price and/or limiting increases, resisting wage increases, looking for cheaper suppliers, and other (left to the organisation to define). For workforce alternatives, rankings from 0 to 8 were needed covering: internal redeployment and/or retraining, short-time working, reduced overtime working, temporary lay-offs, voluntary early retirement, restricted recruitment/termination of the use of temporary workers, reductions in sub-contracting, and other. The results obtained are presented in Table $7 .{ }^{12}$ The most important measures, introduced mostly in conjunction with workforce reductions ( $c f$. Table 6), were sales promotion and looking for cheaper suppliers, although holding back on product price was relatively more important for a minority of organisations (as indicated by the divergence between the relative mean and median rankings). On the workforce side, redeployment/retraining, reduced overtime, restricted recruitment (often through the termination of temporary workers' contracts), and voluntary early retirements were important. ${ }^{13}$ As to significant differences across the three overall restructuring strategies, an

12 Similar results were obtained by Savage (1989, Table 6A), who considered labour market adjustment methods in the event of a downturn in demand.

13 A similar study, carried out in Britain by ACAS (1986) and covering the early 1980s, also sought information on measures to minimise redundancies. Covering only the workforce side, the results are very similar with "restriction of recruitment" mentioned $74 \%$ by respondents, followed by "retraining/redeployment" (61\%), "reduction in overtime" (59\%), "early retirement" $(58 \%)$, "termination of temporary staff" $(56 \%)$, "short time working" $(33 \%)$, "reduction of contracting out" $(24 \%)$, and "other" (8\%). 


\section{Richard Harris and Bridget Daldy}

examination of the data suggests that organisations embarked on investment and technical change were more likely to promote sales and hold back on product price, and rank redeployment/training and short-time working high for implementation. Intensification is associated more with looking for cheaper suppliers, reduced overtime and also short-time working, but not with voluntary early retirement. The size of the organisation is statistically important for the categories: looking for cheaper suppliers and short-time working. In both instances, these are associated more with smaller (to medium) sized organisations. Lastly, private sector firms having changed ownership since 1987 were more likely to look for cheaper suppliers, initiate redeployment/retraining, reduce overtime and encourage voluntary early retirements. Public sector organisations undergoing a change in ownership status (either corporatisation or privatised) were also associated more with reduced overtime.

Table 7

Alternative measures implemented to avoid (or in conjunction with) gross reductions in the workforce 1988-90

\begin{tabular}{llllll}
\hline Reason & Rank $^{\mathrm{a}}$ & \multicolumn{5}{c}{$\begin{array}{l}\text { Significance of } \\
\chi^{2} \text { test }^{\mathrm{b}}\end{array}$} \\
\hline \hline & mean & median & (i) & (ii) & (iii) \\
Marketing & & & & & \\
Promotion of sales & 3.04 & 4.0 & 0.24 & 0.56 & 0.81 \\
Holding back product price & 2.17 & 0.0 & 0.12 & 0.17 & 0.56 \\
Resisting wage increases & 1.09 & 0.0 & 0.55 & 0.22 & 0.45 \\
Looking for cheaper suppliers & 2.44 & 3.0 & 0.12 & 0.06 & 0.14 \\
Other factors & 0.22 & 0.0 & 0.46 & 0.31 & 0.68 \\
& & & & & \\
Workforce & & & & & \\
Redeployment and/or retraining & 5.74 & 7.0 & 0.20 & 0.34 & 0.17 \\
Short-time working & 0.96 & 0.0 & 0.23 & 0.07 & 0.40 \\
Reduced overtime & 4.26 & 6.0 & 0.07 & 0.27 & 0.01 \\
Temporary lay-offs & 0.00 & 0.0 & 1.00 & 1.00 & 1.00 \\
Voluntary early retirement & 3.65 & 4.0 & 0.21 & 0.33 & 0.01 \\
Restricted recruitment & 3.88 & 6.0 & 0.28 & 0.69 & 0.80 \\
Reduced sub-contracting & 1.17 & 0.0 & 0.28 & 0.80 & 0.29 \\
Other factors & 0.58 & 0.0 & 0.53 & 0.55 & 0.01 \\
\hline \hline
\end{tabular}

- Ranked 5 (or 8)=most important down to $0=$ not a consideration

'See Table 4 for explanation

Once workforce reductions were seen as unavoidable, organisations were asked if they set a target number of jobs to be lost and (irrespective of whether they did) what was the order of sequencing (if any) to achieve job losses. Table 8 shows that $75 \%$ of organisations set a target number of jobs to be lost, while generally the order of sequencing of job losses was natural

\section{Organisational Adjustment and the Labour Market in NZ 75}

wastage first, followed by compulsory redundancies ${ }^{14}$ and early retirement (although the mean value for compulsory redundancies shows that it was immediately put into effect by a significant minority - in fact, over $37 \%$ - of organisations, while $16.7 \%$ of organisations made no use of this option). Voluntary redundancies were not as important, with nearly $46 \%$ of organisations not choosing to sequence this option at all and $25 \%$ ranking it as part of the first phase of obtaining job reductions. The advantages and disadvantages of voluntary redundancies has been discussed by Lewis (1986), and this helps to explain why for some organisations this form of downsizing is not appropriate, while for others it features at an early stage. Since voluntary redundancy minimises the threat of industrial relations problems (primarily because it undermines the ability of workers to resist redundancy by encouraging a split between those who wish to stay and those who wish to go), and because it can also result in a greater number of redundancies than initially planned (especially in larger organisations), it is often an important option for certain sectors. However, since the postredundancy workforce is not necessarily what is required (in terms of skills, training and experience), voluntary redundancy makes manpower planning difficult and does not necessarily slim down the targeted parts of the organisation.

Table 8

Whether there was a target number of job losses and an order of sequencing of gross reductions in the workforce 1988-90

\begin{tabular}{lllllll}
\hline Reason & \multicolumn{3}{c}{ Rank } & \multicolumn{3}{c}{$\begin{array}{l}\text { Significance of } \\
\chi^{2} \text { test }^{\mathbf{n}}\end{array}$} \\
\hline \hline & mean & median & (i) & (ii) & (iii) \\
Job targets set & b & 0.75 & 1.0 & 0.13 & 0.02 & 0.04 \\
& & & & & \\
Order of sequencing of losses & $\mathrm{c}$ & & & & & \\
Natural wastage/attrition & 3.88 & 5.0 & 0.28 & 0.65 & 0.72 \\
Early retirement & 2.38 & 3.5 & 0.76 & 0.14 & 0.04 \\
Dismissals due to ill health/age & 0.96 & 0.0 & 0.80 & 0.18 & 0.03 \\
Voluntary redundancies & 2.08 & 2.0 & 0.96 & 0.18 & 0.08 \\
Compulsory redundancies & 3.08 & 3.5 & 0.37 & 0.93 & 0.32 \\
\hline \hline
\end{tabular}

"See Table 4 for explanation

${ }^{b}$ Coded 1 if yes, 0 if no

${ }^{c}$ Ranked $5=$ phase 1 down to $0=$ not an option used

Organisations setting job targets were more likely to be in the intensification stage of restructuring, smaller, and having undergone a change in ownership during the previous three years, while organisations sequencing early retirements and/or voluntary redundancies had a higher probability of being larger and/or recently privatised (or corporatised) public sector organisations.

14 Again, see Savage (op.cit), who found that attrition was a popular short-term adjustment method, while layoffs were favoured in the longer-term. 
Organisations were then asked if they employed specific criteria for selection of workers for compulsory redundancy; and/or specific arrangements designed to attract particular categories of workers to volunteer for redundancy; and/or did the organisation have particular criteria used to identify posts that would not be re-filled when the incumbent left the organisation. When the answer to any of these questions was yes, the organisation was asked to rank among a set of (mostly) predetermined choices. Information was also gathered separately for manual and non-manual employees. The results from asking whether specific criteria were actually used are presented in Table 9 , showing that this occurred in only a minority of cases. The figures in parentheses show the percentage using specific criteria when limited to those organisations who used each particular option to reduce the workforce. While the propensity to use specific criteria rises (especially for voluntary redundancy), there is still a tendency for organisations to choose workers without reference to a laid down set of procedures. In the majority of cases where specific criteria were not used, it was the personnel manager who used his/her own judgement to select workers (or jobs) for redundancy. There was little difference with respect to manual vis a vis non-manual workers, although large companies were more likely to use specific criteria for compulsory non-manual redundancies while private sector companies experiencing a change in ownership were more likely to identify specific criteria for identifying posts that were not to be refilled when the incumben left.

Table 9

Were specific criteria used for selecting compulsory and/or voluntary redundancies and/or to identify posts for attrition

\begin{tabular}{|c|c|c|c|c|c|}
\hline \multirow[t]{2}{*}{ Form of job loss } & \multicolumn{2}{|c|}{ Frequency $(\%)^{\mathrm{a}}$} & \multicolumn{3}{|c|}{$\begin{array}{l}\text { Significance of } \\
\chi^{2} \text { test }^{b}\end{array}$} \\
\hline & & & (i) & (ii) & (iii) \\
\hline \multicolumn{6}{|c|}{ Compulsory redundancy } \\
\hline Manual workers & 37.5 & $(45.0)$ & 0.82 & 0.60 & 0.64 \\
\hline Non-manual workers & 37.5 & $(45.0)$ & 0.33 & 0.11 & 0.78 \\
\hline \multicolumn{6}{|l|}{ Voluntary redundancy } \\
\hline Manual workers & 37.5 & $(57.1)$ & 0.67 & 0.92 & 0.20 \\
\hline Non-manual workers & 41.7 & $(64.3)$ & 0.70 & 0.35 & 0.43 \\
\hline \multicolumn{6}{|l|}{ Natural wastage } \\
\hline Manual workers & 25.0 & $(30.0)$ & 0.46 & 0.23 & 0.06 \\
\hline Non-manual workers & 25.0 & $(28.6)$ & 0.59 & 0.55 & 0.11 \\
\hline
\end{tabular}

- Figures in parentheses refer to percentage using specific criteria who actually used this option to reduce job numbers ( $c f$. Table 8)

${ }^{\mathrm{b}}$ See Table 4 for explanation
Tables 10 and 11 show that for those organisations that did employ specific criteria compulsory redundancies were linked to the job being abolished, last in/first out (for manual workers), and levels of skills or qualifications. ${ }^{15}$ Non-manual workers were also more likely to be selected on the basis of health and age, and the efficiency of the individual. Negotiation with unions was ranked as being relatively unimportant. As to voluntary redundancies, the location of the individual (by department or area) was the overriding criterion used. Skills and qualifications were the next most important feature, but few organisations ranked this criterion very highly (for both manuals and non-manuals, over $83 \%$ of organisations that used criteria ranked skills and qualifications as not important, while the others ranked these criteria in the top two). For natural wastage, the occupation/job category of the post was ranked very highly, followed by departmental location.

As to significant differences across the three (overall) restructuring strategies, for manual workers there was a greater probability that intensification and investment and technical change strategies were linked to organisations ranking job abolition highly for compulsory redundancies, while job location (by department) was ranked relatively highly for organisations rationalising and using specific criteria to achieve natural wastage. For nonmanuals, organisations embarked on a strategy of investment and technical change were more likely to rank ill health and age as prominent criteria for compulsory redundancy. As to differences due to size, larger organisations were relatively more likely to target manual workers in specific departments and locations for voluntary redundancy.
15 The results from the survey by ACAS (1986, Table 8) show a similar position for British redundancies during the early 1980 s. 
Table 10

Criteria used to identify workers/posts for severance: manual workers

\begin{tabular}{llllll}
\hline Form of job loss and criteria used & Rank & \multicolumn{5}{c}{$\begin{array}{l}\text { Significance of } \\
\chi^{2} \text { test }^{\mathrm{b}}\end{array}$} \\
& & \multicolumn{5}{c}{ mean } & median & (i) & (ii) & (iii) \\
Compulsory redundancies & & & & & \\
Last in/first out & 5.00 & 7.0 & 0.45 & 0.94 & 0.40 \\
Job abolished & 6.11 & 8.0 & 0.09 & 0.35 & 0.38 \\
By negotiation with union(s) & 2.67 & 0.0 & 0.07 & 0.05 & 0.69 \\
Part-time workers first & 0.00 & 0.0 & 1.00 & 1.00 & 1.00 \\
Ill health/older workers & 2.68 & 0.0 & 0.65 & 0.13 & 0.39 \\
Levels of skills or qualifications & 4.78 & 7.0 & 0.93 & 0.30 & 0.20 \\
Efficiency of individual & 2.11 & 0.0 & 0.18 & 0.22 & 0.20 \\
Other & 0.89 & 0.0 & 0.17 & 0.57 & 0.78 \\
& & & & & \\
Voluntary redundancy & & & & & \\
Newest appointees & 0.68 & 0.0 & 0.54 & 0.32 & 0.02 \\
Part-time workers & 0.00 & 0.0 & 1.00 & 1.00 & 1.00 \\
Workers with ill-health & 1.56 & 0.0 & 0.70 & 0.57 & 0.72 \\
Older workers nearing retirement & 0.78 & 0.0 & 0.53 & 0.57 & 0.87 \\
Lower skilled or qualified & 2.56 & 0.0 & 0.56 & 0.08 & 0.14 \\
Lower efficiency individuals & 1.68 & 0.0 & 0.66 & 0.41 & 0.27 \\
Workers in targeted & 7.00 & 8.0 & 0.66 & 0.05 & 0.27 \\
departments/locations & & & & & \\
Other & 0.00 & 0.0 & 1.00 & 1.00 & 1.00 \\
& & & & & \\
Attrition & & & & & \\
Occupation/job category & 2.33 & 3.0 & 0.32 & 0.45 & 0.21 \\
Job location:area & 1.67 & 1.5 & 0.32 & 0.54 & 0.08 \\
Job location:department & 2.00 & 2.5 & 0.10 & 0.19 & 0.81 \\
Other & 0.67 & 0.0 & 0.61 & 0.08 & 0.48 \\
\hline
\end{tabular}

'Only responses from organisations who indicated they use criteria are included (see Table 9) ${ }^{\mathrm{b}}$ See Table 4 for explanation

Lastly, information was sought on which categories of workers were more likely to suffer from downsizing. Organisations were asked to indicate if specific occupation groups were more prone or less prone to reductions. Table 12 shows that manual grades were more prone to job losses, especially unskilled manual workers, while technical staff were the least likely to be affected by downsizing. As to any associations with overall strategies, organisations embarked on rationalisation were more likely to make clerical workers more prone to reductions, while both rationalisation and intensification was linked to an above average reduction in unskilled manuals. The privatisation (or corporatisation) of public sector organisations was more closely associated with managers and technical workers being more prone to reductions, while both private and public sector changes in ownership were associated with the higher propensity for unskilled manuals to loose their jobs. Overall, these results are what might be expected given the movement towards more flexible workforces.

Table 11

Criteria used to identify workers/posts for severance: non-manual workers

\begin{tabular}{|c|c|c|c|c|c|}
\hline \multirow[t]{2}{*}{ Form of job loss and criteria used ${ }^{2}$} & \multicolumn{2}{|l|}{ Rank } & \multicolumn{3}{|c|}{$\begin{array}{l}\text { Significance of } \\
\chi^{2} \text { test } t^{b}\end{array}$} \\
\hline & mean & median & (i) & (ii) & (iii) \\
\hline \multicolumn{6}{|l|}{ Compulsory redundancies } \\
\hline Last in/first out & 2.89 & 0.0 & 0.27 & 0.99 & 0.43 \\
\hline Job abolished & 7.89 & 8.0 & 0.54 & 0.53 & 0.67 \\
\hline By negotiation with union(s) & 1.78 & 0.0 & 0.62 & 0.36 & 0.49 \\
\hline Part-time workers first & 0.68 & 0.0 & 0.54 & 0.53 & 0.67 \\
\hline Ill health/older workers & 3.22 & 5.0 & 0.10 & 0.54 & 0.89 \\
\hline Levels of skills or qualifications & 6.22 & 7.0 & 0.18 & 0.77 & 0.27 \\
\hline Efficiency of individual & 3.56 & 5.0 & 0.84 & 0.16 & 0.21 \\
\hline Other & 0.00 & 0.0 & 1.00 & 1.00 & 1.00 \\
\hline \multicolumn{6}{|l|}{ Voluntary redundancy } \\
\hline Newest appointees & 1.00 & 0.0 & 0.75 & 0.13 & 0.08 \\
\hline Part-time workers & 0.50 & 0.0 & 0.47 & 0.68 & 0.81 \\
\hline Workers with ill-health & 0.70 & 0.0 & 0.47 & 0.68 & 0.81 \\
\hline Older workers nearing retirement & 1.50 & 0.0 & 0.75 & 0.77 & 0.41 \\
\hline Lower skilled or qualified & 3.00 & 0.0 & 0.61 & 0.30 & 0.28 \\
\hline Lower efficiency individuals & 1.30 & 0.0 & 0.75 & 0.77 & 0.41 \\
\hline $\begin{array}{l}\text { Workers in targeted } \\
\text { departments/locations }\end{array}$ & 6.30 & 8.0 & 0.71 & 0.60 & 0.34 \\
\hline Other & 0.00 & 0.0 & 1.00 & 1.00 & 1.00 \\
\hline \multicolumn{6}{|l|}{ Attrition } \\
\hline Occupation/job category & 2.57 & 4.0 & 0.36 & 0.51 & 0.43 \\
\hline Job location:area & 1.43 & 0.0 & 0.45 & 0.57 & 0.24 \\
\hline Job location:department & 1.86 & 2.0 & 0.33 & 0.34 & 0.58 \\
\hline Other & 0.57 & 0.0 & 0.51 & 0.11 & 0.39 \\
\hline
\end{tabular}

- Only responses from organisations who indicated they use criteria are included (see Table 9) See Table 4 for explanation 
Table 12

Were certain occupations more/less prone to reductions

\begin{tabular}{lllllll}
\hline Occupation & \multicolumn{3}{l}{ Frequency $(\%)^{\mathrm{a}}$} & \multicolumn{3}{l}{$\begin{array}{l}\text { Significance of } \\
\chi^{2} \text { test }^{\mathrm{b}}\end{array}$} \\
\hline \hline & more & less & (i) & (ii) & (iii) \\
Managers & 12.5 & 37.5 & 0.71 & 0.40 & 0.05 \\
Technical staff & 4.2 & 45.8 & 0.56 & 0.73 & 0.08 \\
Sales staff & 12.5 & 37.5 & 0.61 & 0.20 & 0.31 \\
Clerical staff & 29.2 & 16.7 & 0.15 & 0.85 & 0.03 \\
Skilled staff & 29.2 & 20.8 & 0.55 & 0.27 & 0.32 \\
Unskilled staff & 50.0 & 8.3 & 0.20 & 0.75 & 0.21 \\
\hline
\end{tabular}

"Difference between 100 and the sum of "more" and "less" indicates an answer of "average" or the organisation did not have this category of worker

${ }^{\mathrm{b}}$ See Table 4 for explanation

\section{Summary and conclusion}

Adjustments taking place at the organisational level that have been identified in the international literature (for example, Kanawaty, et al., 1989) have clearly been important in the New Zealand context. The 24 case study organisations considered in this paper have been expanding into new product lines, new markets, and they have introduced new technology. These changes have been closely associated with the use of new work practices, productivity growth and reductions in labour costs (Table 3). A major consequence has been plant closures and an overall contraction of the labour force. Thus, this study has focused on how restructuring at the organisational level has affected the workforce.

Considering the major gross staff reductions in the New Zealand workforce in recent years, these have mostly centred around moves to restructure because of increased competition, rather than because of any short run cyclical downturns in demand. Hence, in the organisations examined in this study improving competitiveness/efficiency and reducing costs were the most frequently cited reasons for downsizing, followed by the reorganisation of work methods. This is in line with the general movement towards greater flexibility that is now seen as crucial for remaining competitive in a changing product market environment.

Workforce reductions were a fairly automatic response for most organisations and other alternative measures were used in conjunction with (rather than as an alterative to) shedding staff. These included expanding markets and redeployment and training, which again is consistent with the general trend towards shedding inflexible workers and broadening the range of skills and tasks of remaining employees (cf. the discussion in Section 1). In fact $75 \%$ of organisations set a target number of jobs to be lost with the most common order of sequencing of job losses being natural wastage first, followed by compulsory redundancies, early retirement, voluntary redundancies and finally dismissals due to ill health/age factors.
Organisational Adjustment and the Labour Market in NZ 81

There was a tendency for (usually the Head Office of) organisations to choose workers without reference to any laid down set of procedures; rather it was left to the personnel manager to select workers for redundancy. But for those that did employ specific criteria, compulsory redundancies were linked to the job being abolished, to last in/first out (for manual workers), and to skills or qualifications. Non-manual workers were more likely to be selected for redundancy on the basis of the job being abolished, or their health and age, or the efficiency of the individual. When voluntary redundancies occurred the organisation targeted departments and/or specific locations, while in the case of natural wastage, the occupation/job category of the post was ranked as most important, followed by department location. These results tend to suggest that the process of downsizing has not necessarily been carried out efficiently; firms may find that in their haste to shed labour a good deal of valuable "human capital" has been lost which may prove costly to replace.

Further analysis was carried out into the importance of the relative size of the organisation, the impact of changes in ownership, and whether the type of restructuring strategy had resulted in (or affected the process of) restructuring. All of these factors were found to be important although no clear pattern emerges. In general, our results have confirmed that the process of (labour market) change identified in other countries is now having a fundamental impact in New Zealand. This is likely to continue unabated while the economy remains open to those competitive pressures that are shaping world product and labour markets. As to other relevant research questions eg. concerning the impact of redundancy payments (and whether these have helped or hindered change), there is obviously the need for a great deal of further research work.

\section{References}

ACAS (1986), Redundancy Arrangements: The 1986 ACAS Survey, Occasional Paper 37, ACAS, London.

Ammon, C. (1989), Restructuring Electricorp: the Labour Process, Profit, Technology and Work Organisation, New Zealand Journal of Industrial Relations, 14: 109-118.

Ashton, D., M. Maguire and M. Spilsbury (1990), Restructuring the Labour Market: The Implications for Youth, Macmillan, London.

Atkinson, J.S. (1985), Flexibility: Planning for an Uncertain Future, Manpower Policy and Practice, 1, Summer 1985.

Crokett, G. et al (1991), The Impact of Unions on Workplace Productivity in Australia, paper presented at 20th Conference of Economists, Hobart, 1991.

Cyert, R.M. and D.C. Mowery (1987), Technology and Employment: Innovation and Growth in the US Economy, National Academy Press, Washington.

Daniel, W.W. (1987), Workplace Industrial Relations and Technical Change, Frances Pinter, London. 
Edgren, G. (1990), Employment Adjustment and the Unions: Case Studies of Enterprises in Asia, International Labour Review, 129: 629-648.

Freeman, C (1986), Technical Change In Economic Development, in A. Amin and J. Goddard (eds.) Technological Change, Industrial Restructuring and Regional Development, Allen Unwin, London.

Gershuny, J. and T. Miles (1983), The New Service Economy: The Transformation of Employment in Industrialised Economies, Francis Pinter, London.

Goodman, J. (1989), Industrial Relations and Restructuring in Manufacturing: Three Case Studies in the United Kingdom, International Labour Review, 128: 601-620.

Gray, A. (1988), State Sector Restructuring - A Year After Redundancy, Report for the Wellington Regional Council and Wellington Regional Employment \& Access Council, Gray Matter Research Ltd.

Harris, R.I.D. and B. Daldy (1992), Labour Market Adjustment in the Waikato, a Report to the Department of Labour, University of Waikato, Hamilton.

Houghton, RM et al. (1987), Redundancy in the Woollen Textile Industry: Mosgiel Limited Workers Five Years Later, Business Development Centre, University of Otago.

IMS (1985), New Forms of Work Organisation, Institute of Manpower Studies, IMS Manpower Commentary, No. 30, Brighton, 1985.

Kanawaty, G. et al. (1989), Adjustment at the Micro Level, International Labour Review, 128 : 269-296.

Kassalow, E.M. (1989), Technological Change: American Unions and Employers in a New Era, in G.J. Bamber and R.D. Lansbury (eds.), New Technology: International Perspectives on Human Resources and Industrial Relations, Unwin Hyman, London.

Lewis, P. (1986), Voluntary Redundancy: a Preliminary Investigation, Employee Relations, 8: $39-44$.

Machin, S.J. and M.B. Stewart (1990), Unions and the Financial Performance of British Private Sector Establishments, Journal of Applied Econometrics, 5: 327-350.

Machin, S.J. and S. Wadhwani (1991a), The Effects of Unions on Organisational Change and Employment, Economic Journal, 101: 835-854.

Machin, S.J. and S. Wadhwani (1991b), The Effects of Unions on Investment and Innovation: Evidence from WIRS, Economic Journal, 101: 324-330.

Massey, D. and R. Meegan (1982), The Anatomy of Job Loss, Methuen, London.
Organisational Adjustment and the Labour Market in NZ 83

Melser, P et. al. (1982), Patea After the Freezing Works, Ministry of Works \& Development, Wellington.

Murray-North Ltd. (1989), The NZ Co-operative Dairy Company Ltd. Kerepeni Factory Closure, a Socio-economic Impact Study.

National Organisation for Women (1982), Shut Down: A Report on the Closure of Marlborough Lingerie Ltd., Blenheim, and the Effects of Redundancy on the Workers, Blenheim, Marlborough.

NEDO (1986), Changing Working Patterns: How Companies Achieve Flexibility to Meet New Needs, National Economic Development Office, London.

Nicholls, M. and D. Piesse (1982), The Consequence of Closure, Auckland Regional Authority, Auckland.

OECD (1990), New Zealand, OECD Economic Surveys 1990/91

Piganiol, C. (1989), Industrial Relations and Enterprise Restructuring in France, International Labour Review, 128: 621-638.

Porter Report (1991), Upgrading New Zealand's Competitive Advantage, Oxford University Press, Auckland.

Romesburg, H.C. (1984), Cluster Analysis for Researchers, Lifetime Learning Publications, Belmont, California.

Savage, J. (1989), Internal Labour Markets, NZIER Research Monograph 45, Wellington.

Savage, J. and A. Bollard (1990), Turning It Around: Closure and Revitalisation in New Zealand Industry, Oxford University Press, Auckland.

State Services Commission-Waikato United Council (1988), Coping with Change? The Huntly Experience, Technical Bulletin Series RPS 9/2

Storper, M. and A.J. Scott (1990), Work Organisation and Local Labour Markets in an Era of Flexible Production, International Labour Review, 129: 573-591.

Willman, P. (1986), Technological Change, Collective Bargaining and Industrial Efficiency, Clarendon Press, Oxford. 